\title{
IMPLEMENTATION POLICIES ENHANCING HUMAN DEVELOPMENT INDEX IN THE DISTRICT PANDEGLANG PROVINCE BANTEN
}

\author{
Tauficurokhman \\ e-mail: taufiqurakhman@yahoo.com
}

\begin{abstract}
ABSTRAK
Fenomena yang dijadikan obyek penelitian adalah implementasi kebijakan peningkatan Indeks Pembangunan Manusia (IPM) di Kabupaten Pandeglang Provinsi Banten. Tujuan penelitian adalah membahas implementasi kebijakan peningkatan Indeks Pembangunan Manusia yang dilakukan dengan program Jaminan Sosial Rakyat Banten Bersatu (Jamsosratu). Penelitian menggunakan pendekatan kualitatif. Penentuan informan penelitian menggunakan purposive sampling technique. Pengumpulan data sekunder menggunakan studi kepustakaan dan studi dokumen. Pengumpulan data primer menggunakan teknik wawancara dan observasi. Analisis data menggunakan metode analisis deskriptif yang dikembangkan dengan analisis triangulasi. Hasil penelitian menujukkan bahwa Implementasi Kebijakan Peningkatan Indeks Pembangunan Manusia (IPM) di Kabupaten Pandeglang Provinsi Banten mencakup pengorganisasian, penafsiran, dan penerapan. Aktivitas pengorganisasian, penafsiran, dan penerapan kebijakan peningkatan IPM tersebut secara kondisional dan fungsional dipengaruhi oleh isi kebijakan dan konteks implementasi kebijakan.
\end{abstract}

Kata Kunci: Implementasi kebijakan, Pemerintah, Indeks Pembangunan Manusia.

\begin{abstract}
The phenomenon that made the object of research is the implementation of policies for enhancing the Human Development Index (HDI) in Pandeglang Banten Province. The research objective was to discuss the implementation of policies for enhancing the Human Development Index conducted by the Social Security program Banten People Unite (Jamsosratu). The study used a qualitative approach. Determination of research informants using purposive sampling technique. Secondary data collection using literature study and study documents. Primary data collection using interviews and observation techniques. The data analysis
\end{abstract}


using descriptive analysis method developed by triangulation analysis. Results of the study show that Policy Implementation Improved Human Development Index (HDI) in Pandeglang Banten province covers organization, interpretation, and application. Organizing activities, interpretation, and application of the policy of increasing HDI conditionally and functional policy is influenced by the content and context of policy implementation.

Keywords: Policy implementation, Government, Human Development Index.

\section{INTRODUCTION}

\section{Research Background}

Implementation of policies for enhancing the Human Development Index (HDI) in Pandeglang in Banten province formulated Banten Governor Regulation No. 2 Year 2013 about Social Security Implementation Guidelines People Unite Banten (Jamsosratu). In the policy contained the following provisions:

Household Target hereinafter abbreviated RTS is a family who becomes the target of a unified social security Banten people who refer to the collection of social protection programs in 2011; (2) Social Security Banten People Unite hereinafter abbreviated Jamsosratu is institutionalized scheme to ensure Banten people who come from disadvantaged groups of households based on data PPLS in 2011 as participants in the social security of the people of Banten unified conditional cash social assistance and social welfare insurance coverage; (3) social protection are all efforts aimed at preventing and addressing the risk of shocks and social vulnerability; (4) Social security is institutionalized scheme to ensure that all people in order to meet the basic needs of a decent life; (5) Social Assistance Social Security People's Conditional Cash Banten United hereinafter abbreviated BSTB is giving cash to targeted households who are required to check their family members to health facilities and / or send their children; (6) Insurance Social Welfare Social Security Banten People Unite hereinafter abbreviated Askesos Jamsosratu is a system of social protection for the main breadwinner target households as informal sector workers in the form of collateral substitute family income; and (7) social assistance is a process to establish and build social relationships between the participants of the social security companion Banten people unite in order to facilitate the implementation and services that can be more helpful in improving the social welfare of its participants.

Target efforts to improve the functioning and social empowerment through programs Jamsosratu Banten 
prosperous society directed towards the poor. Total population Pandeglang BPS data in 2013 as many as 1,133,215 people. With the number of poor people decreased in the two periods of 2005-2010 and 2011-2012. First: the period of 2005-2010, the year 2005 approximately 13.89 per cent, in 2010 amounted to 11.14 percent (as a percentage of the number of poor people fell 2.75 percentage points). Secondly, the period in 2011-2012, the year 2012 as many as 209655 people (9.80 percent); In 2011 as many as 219 592 people or about 9.28 percent. (The poor soul fell 99.37, down 0.55 percent). A decrease in the percentage of poor and poverty shows the success of Pandeglang implement government policy implementation to overcome the poor.

By contrast in 2013 the percentages of poor people Pandeglang rise, when compared to the year 2014 as many as 125315 people $(0.98$ percent). This is because there is a central government policy against rising fuel prices. Ie in 2013 the number of poor people as much as 230 364 people (about 10.25 percent), while in 2014 decreased by 105049 (9:27 per cent). However, in 2014 Pandeglang still the largest category of poor people throughout the province of Banten.

The total population of Banten in 2013 amounted to 9,978,932 inhabitants. Based on the record of 2014 mentions BPS, Population
Growth Rate (LPP) Banten around 2.79 percent. LPP is the seventh highest national poverty rate in 2014 amounted to 5.35 per cent or 622840 inhabitants. With the percentage of poor population decreased in 2014 put Banten order to 4 out of 33 provinces, after Jakarta, Bali, South Kalimantan. The number of poor people below the national average of 11.25 percent, totaling 28.28 million and has exceeded targhet MDGs by 7.5 percent in 2015. This shows the government's success in reducing the percentage of poverty Banten and the number of poor people.

With these data, the Pandeglang and Banten province managed to reduce poverty and poor presentation, but not optimal raise the average rate of HDI. Therefore the continuation of the implementation of government policy implementation and Pandeglang Banten run Jamsosratu program is very important. Why is that? Because achievements of IPM in Pandeglang in Banten and the trend pattern of increase is not yet optimal.

BPS data in 2014 mentioned IPM Pandeglang in 2011 through 2013; successively in 2011 amounted to 68.77; in 2012 amounted to 69.22 and in 2013 amounted to 69.64 (HDI Pandeglang average of 69.14 with an average increase of about 0.66 ). The percentage increase in HDI is above Pandeglang Lebak 68.82, but under the Serang District 70.25. 
Medium HDI Banten period in 2011; 2012 and 2013 respectively: in 2011 amounted to 70.95 ; in 2012 amounted to 71.22; and in 2013 amounted to 70.48 (average HDI Banten around 70.53 with an average increase of increase of about 0.42). The percentage increase in Banten HDI is above 71.31 Gorontalo province, but under the Province of Southeast Silawesi 72.14. Ideally, the achievements of IPM in Pandeglang and Banten together with the achievements of the national average, which is around 73.29. Achievement of Human Development Index (HDI) includes educational variables, health variables and variable purchasing power. Ha lines refer to the parameter that was first introduced Mahbub ul $\mathrm{Haq}$ as the "Human Development Index (HDI), which the HDI is a measure of the aggregate of the basic dimensions of human development which comprises aspects of survival, knowledge and purchasing power. If viewed from the future development of the time, the HDI ranges from 0 to 100 . The closer to 100 , it is indicated improved human development.

The United Nations Development Program (UNDP) human development status divides into three (3) criteria, i.e low HDI (less than 50), medium or medium HDI (values between 50 to 79.9) and high HDI (HDI value of 80 or more). But there is also the middle class divides into lower middle IPM (Score 50 to 65.9) and high HDI (Score 66 to 79.9$)$.
Based on the criteria of the achievements of the HDI, HDI achievement Pandeglang and Banten province in the category of medium or medium. That is, the achievement of IMP Pandeglang and Banten Province has not been optimal. Not optimal achievement of HDI, according to data obtained from RPJMD Pandeglang and Banten caused by several things, namely: (1) Life Expectancy (AHH) is low; (2) Maternal Mortality Rate (MMR) and Infant Mortality Rate (IMR) is high; (3) Average Old School (RLS) is still low; (4) Economic disparities are relatively concern; (5) The high malnutrition that occurred in Banten; and (6) The high level of unemployment that can inflict high poverty.

Not optimal HDI figures above, according to the BPS 2014 mentions the root of the problem is: first, life expectancy (AHH) is low, Maternal Mortality Rate (MMR), Infant Mortality Rate (IMR) and the high incidence of malnutrition, including root causes related the health of individuals and families. Second, the average Old School (RLS) is still low, including the root causes related to education. Thirdly, the relatively poor economic disparity. And high levels of unemployment, including the root causes associated with employment, income communities and infrastructure area, especially in the area of environmental infrastructure slums. 
With a background already described above, the authors take Dissertation Title: Policy Implementation Improved Human Development Index in Pandeglang Banten Province.

\section{Problem Formulation}

Based on the description in the background research, the formulation of the problem posed by the following research questions:

How Policy Implementation Improved Human Development Index which includes the organization, interpretation, application of which is influenced by the policy content and context of policy implementation in Pandeglang Banten?

\section{Research Objective}

With the formulation of the problem, then set the goal of research is to discuss the implementation of policies for enhancing the Human Development Index, organization, interpretation, application of which is influenced by the policy content and context of policy implementation in Pandeglang Banten Province; and acquiring a new concept that can be used as a contribution to the development of science, particularly the development of Government.

\section{Research Methods}

The study used a qualitative research approach undertaken by descriptive analysis method. Determination of 7 elements informants using purposive sampling technique. Secondary data collection using Library Studies and Study Documents, primary data collection using interviews and observation techniques. Data analysis techniques using Descriptive Analysis Method developed by triangulation analysis according to viewpoint: First, decision makers informant Jamsosratu (Secretary of Banten, Pandeglang Regent, Secretary Pandeglang, Banten Head of Social Services and Pandeglang. The numbers there are five informants. Second, implementing informant Jamsosratu; (section head of social services and Pandeglang Banten; the operators at the level of Banten; the companion in Pandeglang. The numbers there are eleven informants. Third, participants or recipients Jamsosratu (RTSM) (RTSM taken three people from each of the six sub-districts Pandeglang, for the six districts a total of eighteen). Totally informants in this study are thirty four informants.

\section{RESULTS AND DISCUSSION}

Research results and discussed according to the model approach to public policy implementation Grindle 
(1980: 9) who said that the successful implementation of policies determined by the Content of policy and Context of implementation. Content of policy include affected interests; type of benefits; extent of change envisioned; site of decision making; program implementer; resource committed. Context of implementation include power, interests, and strategies of actors Involved; institution and regime characteristic; compliance and responsiveness. With this theoretical basis, the implementation of policies Improved Human Development Index in Pandeglang in question is the implementation of Banten Governor Regulation No. 2 Year 2013 About Social Security Implementation Guidelines People Unite Banten in Banten Province. Principles of the results of the implementation of the gubernatorial regulation are the following:

Interests that affect (Interest Affected) the intensity of policy implementation clearly requires specific attention. That is, interest affected with regard to a variety of interests that influence policy implementation process. This suggests that the implementation of the policy of increasing the Human Development Index in Pandeglang Banten involving multiple parties in different sectors and levels. Each party would have its own interests. Directly or sodium absorption ratio-interest directly affect policy implementation process improvement Human Development Index (HDI). However, in accordance with the goals and objectives of implementation, then the interests of the most prominent influence the policy implementation process improvement in the Pandeglang IPM is the interest of targeted households (RTS) or poor households (RTM) which is a participant Jamsosratu. Number of STS in Pandeglang as 8620 RTM.

Type of benefits (Type of Benefits): Implementation of policies for enhancing the Human Development Index in Pandeglang has certain benefits, especially the benefits for program participants Jamsosratu. real for individuals and groups of people who were targeted implementation. The benefits of poor households or participants Jamsosratu of implementation Jamsosratu system. For example, the benefits received directly, ie Social Aid Conditional Cash for Rp.1.500.000, - (one and a half million dollars). Other direct benefits are that poor households or Jamsosratu participants can take advantage of health facilities and educational facilities with ease. Indirect benefits are very significant in reviving the hopes of poor households is the Social Welfare Insurance for the main breadwinner in the Target Households as well as the development of the culture of saving through the obligation to save each month a minimum of $\mathrm{Rp} 10.000$, -. These benefits would not only cover the economic dimension, but also includes a social dimension.

The degree of desired change (extent of change envisioned). In Jamsosratu implementation perspective, the degree of change that occurred among participants Jamsosratu measured by indicators of lifetime (longevity) were identified 
from life expectancy, and indicatorndikator knowledge (knowledge) were identified from adult literacy. Although each participant Jamsosratu received Conditional Cash Transfer. Yet indicators of living standards (standard of living) were identified from real income per capita head of Poor Households seem to have highlighted. This indicates that the strengthening of the quality of human resources in the process of implementing the policy of increasing the Human Development Index in Pandeglang becomes important.

Location of decision-making (site of dicision making): Implementation of the policy to increase the Human Development Index in addressing the problem of poverty in Pandeglang clearly influenced by the location decisions. Location of decisionmaking directly correlated with the decision kepetingan RTM is attached to the Companion Program Jamsosratu. Because the companion is in the District and served directly assist potential participants and attendees Jamsosratu. Then by itself it can be said that the location decisions that determine acceptance or non-acceptance of poor households as participants Jamsosratu be close to poor households. With this proximity, considerations becomes not too difficult in deciding various matters related to the implementation Jamsosratu.

Executing the program (Program Implementer). Goals and objectives of policy implementation is achieved through the implementation of various programs. Program implemented is complete immunization for pregnant women and infants, poor scholarship programs and cultural programs for participants Jamsosratu saving, direct cash assistance program, and the program Askesos (Social Welfare Insurance) for the head of household employment targets (RTS / RTM). The programs are presented, besides directed to improve the health of poor households and improve children's education are also among poor households; these programs are also targeted to increase the economic capacity of poor households. While the implementation of an insurance program seems to be aiming to raise awareness and motivation among poor households to look at the importance of the future of the family, especially the children's future. Executing Jamsosratu program is Jamsosratu Control Team consisting of Social Services, health department, department of education, employment BPJS and PT. Pos Indonesia and the field worker.

Resources used (Resources Committed). Implementation of the policy of increasing IPM requires resources to support the goals and objectives achieved optimally. Implementation of the policy of increasing the HDI in Pandeglang gained the support of various resources. Support resources is not limited to any financing power suumber support. Implementation of the policy of increasing the HDI in Pandeglang supported by human resources play an important role, which is a companion who were recruited and trained to provide social services and social empowerment; health workers and health facilities to provide health services; teachers and educational facilities to provide educational services. 
Power, interests, and strategies of the actors involved (Power, Interest, and Strategy of -Actor Involved). Power, interests, and strategies of the parties involved affect the effectiveness of policy implementation HDI improvement in the Pandeglang. The authority of the critical success factors is the authority budgeting, coordinating authority by the government of Banten Province. Social Service Banten as TPJ-Provincial (Provincial Jamsosratu Control Team) in the implementation acts as Executing Agency or the Leading Sector. In its implementation on the ground involved SKPD and related institutions. SKPD and institutions referred to, among others, the Department of Health for the provision of health services and verification of commitments RTS on health; Religious Education Office and the Regional Office for the provision of educational services and verification RTS commitment to the education sector; PT. Pos Indonesia Banten representative and Employment Representative BPJS Banten. Interesting to note and in priority in the implementation of the program Jamsosratu is in the interests of participants in order to receive aid, access to health and educational facilities as well as banking. Strategies used to streamline the implementation of Jamsosratu by way of jointly provide assistance, support programs of each department related to the participants Jamsosratu.

Characteristics institutions and the regime (Regime Institution and Characteristic). Implementation of the policy of increasing HDI in Banten Provincial Government, including in Pandeglang Kebupaten not escape the influence of the characteristics of an institution that implements policies and also influence local government authority in the process of policy implementation. Social services provincial, district / city. provincial education department, district / city, the provincial health department, district / city, district, village / sub-district, BPJS employment, companion and jamsosratu operator, PT POS. Such institutions would have its own institutional characteristics. This institutional characteristics tercarmin of authority and duties and functions of institutions.

The level of compliance and the response from the executor (Compliance and Responsiveness). The level of compliance and implementing policies for enhancing the response of the Human Development Index in Pandeglang be the deciding factor the successful implementation of the policy. Compliance is necessary to jointly promote IPM Jamsosratu participants. In the process of implementation that needs to be responded Jamsosratu is the recipient of public complaints jamsosratu or not the recipient jamsosratu acceptable manner, in capacity and a solution found its completion.

Research Findings: Beyond the provision of Conditional Cash Transfer, Employment Insurance Polish administration to implement the commitments and obligations of the importance of education, health and economic and development capacity of poor households, the distinctiveness of poverty reduction policies in Pandeglang that are not found in other provinces or other areas. The specificity of the targeted development 
policy implementation to improve the standard of living (levels of living) as proposed by Todaro and Smith (2003, 56) that in almost all developing countries living standards (levels of living) of most of the population tends to be very low, not only compared to the standard of living of people in rich countries, but also with the lifestyle of the elite in their own countries. Low standard of living is manifested quantitatively and qualitatively in the form of very low income level (poverty), lack of decent housing, poor health, provision of education is minimal or even nonexistent, high infant mortality, life expectancy relatively very short, low chances of getting a job, and in many cases there is also a general dissatisfaction and helplessness.

With the increase in the HDI its directionally policy implementation in Pandeglang, then the achievements of IPM certainly not limited only to the increase in per capita income alone as proposed by Todaro and Smith (2003: 68) that a country can do much better at low income levels, and that a large increase in income may contribute relatively little in human development. Thus efforts to improve the welfare of people in an area are not limited to approach the increase in per capita income alone. Other approaches that further enable the development of human resources for the realization of the condition of the welfare of society is also a matter that should be ignored. Achievement of policy implementation in Pandeglang increase in IM refers to indicators HDI (Human Development Index): HDI try to rank all countries from fiscal 0 (the level of the lowest human development) to 1 (the highest level of human development) by three goals or product end development: the lifetime (longevity) as measured by life expectancy, knowledge (knowledge) as measured by the adult literacy are weighted (two-thirds) and the average years of schooling (one-third), and standard of living (standard of living ) as measured by real per capita income, adapted to partitas purchasing power (purchasing power parity or PPP) of the currencies of each country to reflect the cost of living and to meet the assumption of declining marginal utility of income.

If the phenomenon of policy implementation in Pandeglang HDI improvement compared with the indicators used VPS-2013 to determine the level of welfare, namely (1) earnings, (2) consumption or family expenses, (3) the state of residence, (4) residential facilities , (5) the health of family members, (6) the ease of obtaining health services, (7) the ease of entering in level child education, and (8) ease of obtaining transport facilities, the peculiarities of the implementation of these policies may not touch the third indicator, namely the state of residence and indicators The eighth is the ease of getting transportation facilities. This happens because Targets Poor Household (SRTM) was in rural areas that are far from urban amenities.

\section{CONCLUSIONS}

Based on the analysis of the research results can be put forward the following conclusions: 
Policy Implementation Improved Human Development Index in Pandeglang Banten province, organization, interpretation, application. Activity organizing phase (organization), consisting of structuring administrative resources Jamsosratu; forming units Jansosratu in implementing the policy of the provincial, district, township and village; preparation of implementation guidelines and the provision of technical guidance Jamsosratu. Activities stages of interpretation (interpretation) consists of determining the location of granting Jamsosratu activity, the activity of the target collection of Poor Households Jamsosratu receiver, and activities targeting poor households Jamsosratu receiver. Activities stages of the application (application) include mentoring activity Poor Households Jamsosratu receiver, empowerment activities Poor Household Jamsosratu receiver, and service activities Poor Households that include health services, educational services and social services in the insurance field. Organizing activities, interpretation, and application of the policy of improvement of the Human Development Index and functional conditionally affected by the policy content and context of policy implementation. Fill the policy of increasing the Human Development Index in Pandeglang include parameters: (1) The interests that influence Jamsosratu, (2) Type of benefits recipients Jamsosratu, (3) The degree of change to be achieved through the provision of Jamsosratu, (4) Location of decision-making in realizing Jamsosratu, (5) Performance Jamsosratu program implementers, and (6) The resources used to carry out development activities and the provision of health care, education and social protection to the recipient Jamsosratru namely Poor Households in Pandeglang. The context of the implementation of the policy of increasing the Human Development Index in Pandeglang parameters include: (1) The powers, interests, and strategies bureaucratic officials involved in the implementation of policies to improve the functioning Jamsosratu and social empowerment of poor households; (2) Characteristics of the institutions and the regime in the process of policy implementation Jamsosratu that authority as well as the duties and functions of policy implementation units Jamsosratu, and (3) The level of compliance and responsiveness of implementing policies to comply with the instructions on the implementation and technical petujuk Jamsosratu as well as responding to complaints Jamsosratu recipients. Implementation of the policy of increasing policy Human Development Index in Pandeglang not optimal because HDI Pandeglang including upper middle class HDI figures. When compared with the number of district / city in the province of Banten, Pandeglang HDI ranks 
sixth of the seven district / city in the province of Banten.

New concept: new concepts derived from the research is that the concept of the policy of conditional cash transfers, employment insurance polish administration to implement the commitments and obligations of the importance of education, health and the economy which is a component of the HDI forming and developing the capacity of poor households, the peculiarities of prevention policy poverty in Pandeglang Banten province that are not found in other provinces or other areas. There are three objectives of human development, namely (1) lifetime (longevity) as measured by life expectancy; (2) knowledge (knowledge) as measured by the adult literacy are weighted (two-thirds) and the average years of schooling (one-third); and (3) the standard of life (standard of living) as measured by real per capita income.

\section{BIBLIOGRAPHY}

Book:

Anderson, James E, 1994, Public Policy Making, Second Edition, Houghton Miffilin Company, USA

Arinkunto, Suharsimi, 1997. Procedure Research: A Practice Revenue, Jakarta: Rineka Reserved

Bappenas, 2004, Economic Development (Processes, Issues, and Basic Wisdom), Publisher:
Faculty of Economics, University of Indonesia, Jakarta.

Central Bureau Of Statistics. (2010) .Penyempurnaan Preparation of Regional Development Index: CV. Nario Sari. Jakarta

Bungin, Burhan, 2006, Qualitative Research Methodology, Jakarta: PT. King Grafindo Persada.

BPS-Statistics Indonesia, UNDP, BAPPENAS, 2004. National Human Development Report 2004. The Economics of Democracy: Financing Human Development in Indonesia.

Chase, Gordon. 1979. Implementing a Human Service Programs: How Hard Will it Be ?. New York City Creswel, John. W. 1994. Research Design Qualitative and Quantitative Approaches. Sage Publication: New Delhi

Denzim, Norman, $\mathrm{K}$ and Yvonna S. Lincoln. 1994. Handbook of Qualitative Research. California: Sage Publications Inc.

Dunn, William N., 1999, Public Policy Analysis, Yogyakarta: Gadjah Mada University Press.

Downs, Anthony, 1967, Inside bureaucracy, Boston: A Rand Corporation Research

Edward III, George, C. 1980. Implementing Public Policy, Congressional Quarterly Inc., USA.

Edward, G, and Sharkansky, I. 1978. The policy Predicament, San Francisco: WH Freeman and company 
Fisher S. et al. 2000. Working with Conflict: Skills Et Strategies for Action. Bookcrafi, Midsomer Norton, Bath, UK.

Grindle, Merilee S., Politics And Policy Implementation In The Third World, New Jersey: Princeton University Press, 1980.

Hill, Michael and Peter Hupe, 2002. Implementing Public Policy, London: SAGE Publications Ltd.

Hoogerwerf, A, 1978, Governance Studies, Terj.RLL Tobing, Jakarta: Erland

Jones, Charles O, 1977, An Introduction

To The Study of Public Policy Publishing Company Monterey, California: Wesley Longman Publishing Company, Inc.

Kerlinger, Fred. N, 2002, Principles of Behavioral Research, Yogyakarta: Gadjah Mada University Press.

Mazmanian, Daniel A. And Paul A, Sabatier, 1983, Implementation and Public Policy, IllionisGlenview: Scott, Foresman, \& Co.

Marshall, C, Rossman, G.B. 1989. Designing Qualitative Research. California: SAGE Publications. Inc

Miles, M.B. \& Huberman, A.M. (1994). Qualitative Data Analysis: An expanded sourcebook. New York: SAGE Publications.

Moleong, Lexi J. 2000. "Qualitative Research Methodology", Bandung: PT. Teens Rosda paper Neuman, William Lawrence, 1997, Social Research Methods,
London: Needham Heights, Allyn and Bacon.

W. Lawrence, 2000, Social Research Methods Qualitative and Quantitative Approach, Allyn and Bacon: London

Ripley, Randall. B., Franklin, Grace. A, 1990, Policy Implementation and bureaucracy (Second Edition), Chicago, Illinois: The Dorsey Press.

Rosenbloom, David. H., Kravchuk, Robert S., Rosenbloom, Goldman, Deborah, 2002, the Public Administration Understanding Management, Politics and Laws In the Public Sector, Mc Graw Hill: New York

Saefullah, A Djadja. 2008. Thought Contemporary Public Administration. Perspective of Human Resource Management in the Era of Decentralization. Bandung: LP3AN.

Supriatna, Tjahya., And Syaruhdin Yassin, 2013, the Public Policy. Bandung: Indra Prahasta.

Sunggono, Bambang, 1994, Law and Public Policy, Jakarta: Rays Graphic

Sumodiningrat, Gunawan, 1999, Poverty, Theories, Facts and Policy, Jakarta: IMPAC.

Suyatno, Hempri and Suparlan, 2003 Community Development, Yogyakarta: Aditya Media

Solahudin Kusumanegara, 2010. Models and Actors in the Process of Public Policy, Gava Media. 
, 2005, Handout public policy department of political science social and political science faculty UnSoed. Gava Media.

UNDP. (2002). Human Development Report 2002. Deepening Democracy in a Fragmented World. New York: Oxford Uiversity Press,

Joko Widodo. (2010) Analysis of Public Policy, Concepts and Applications KebijakanPublik. Bayumedia Publishing Process. Malang. $183 \mathrm{~h}$.

Todaro, P., Michael and Smith, C., Stephen, 2003, the Economic Development in the Third World, Jakarta: PT. Primary Literacy surge.

Tachjan, H, 2008, the Public Policy Implementation, Bandung: AIPI

Van Meter, Donald S. and Van Horn, Carl E., 1975. "The Policy Implementation Process. A Conceptual Framework ". Administration and Society, Vol.6 No.4. London: Sage Publications, Inc.

Wahab, Abdul Solichin 2004, the Policy Analysis, Jakarta: PT Earth Literacy
Weimer, David L, Adidan R.Vining, 1989, the Policy Analysis Concept and Practice, Prentice Hall, Inc.: New Jersey

Donald P. Warwick, 1979. Integrating Planning and Implementation: A Transactional Approach. Harvard Institute for International Development, Discussion Paper No. 63.

Widodo, MS Joko, 2007, Building Performance-Based Bureaucracy, Malang: Bayumedia

\section{Document:}

Banten Governor Regulation No. 2 Year 2013 About Social Security Implementation Guidelines People Unite Banten in Banten

In Banten province Figures for 2012

Medium Term Development Plan 2012-2017 Banten Year

Human Development Report, (1995), Published for the United Nations Development Programme (UNDP) New York Oxford Oxford University Press. Source: http: //hdr.undp.org/sites/default/ files/reports/.pdf. 